\title{
Use of $16 S$ rDNA Sequencing to Determine Procaryotic Diversity of a Remote Aviation Fuel-Polluted Lentic Ecosystem in Ibeno, Nigeria
}

Ime Udotong $^{1^{*}}$, Mfoniso Uko ${ }^{1}$ and Justina Udotong ${ }^{2}$

${ }^{1}$ Department of Microbiology, University of Uyo, Uyo, Akwa Ibom State, Nigeria

${ }^{2}$ Department of Biochemistry, University of Uyo, Uyo, Akwa Ibom State, Nigeria

\begin{abstract}
Ibeno, the operational base of Mobil Producing Nigeria Unlimited, a subsidiary of ExxonMobil, Nigeria remains one of the most impacted communities by oil and gas activities in the Niger Delta region of Nigeria. Lotic and lentic systems in the region which residents rely on, receive petroleum hydrocarbon inputs almost daily due to oil spills and oily wastes discharges from operators and bunkering activities. This research was carried out to determine the prokaryotic diversity in a remote aviation fuel-polluted lentic ecosystem after 16 years of pollution using metagenomic approaches. DNA extraction from the water samples was carried out using MoBio DNA extraction Kits following the manufacturer's instructions. Extracted DNA fragments were quantified using picogreen and by recording their UV absorption spectra using NanoDrop spectrophotometer. 16S rDNA sequencing was carried out on a Miseq Illumina sequencing platform and Quantitative Insight Into Microbial Ecology (QIIME) bioinformatics pipeline. Analyses revealed the dominance of bacterial and archaeal communities in both polluted and unpolluted water samples. The polluted sample had $93.83 \%$ bacterial and $3.43 \%$ archaeal population while the control sample revealed $58.05 \%$ bacterial and $39.69 \%$ archaeal population. Dominant bacterial phyla from the polluted samples were Proteobacteria, Firmicutes, Actinobacteria, Cyanobacteria, and Chloroflexi while dominant phyla in the unpolluted samples were Proteobacteria, Firmicutes and Actinobacteria. Dominant archaeal phyla from both polluted and unpolluted waters were Euryarchaeota and Crenarchaeota. The use of 16S rDNA metagenomic approach revealed a wide variety of bacterial and archaeal diversity from both polluted and control sites, thus revealing the true ecological status of both sites.
\end{abstract}

Keywords: $16 \mathrm{~S}$ rRNA; DNA sequencing; Prokaryotic diversity

\section{Introduction}

Since the inception of oil and gas exploration and production (O\&G $\mathrm{E} \& \mathrm{P})$ activities in Nigeria and in spite of the increasing revenue from these resources, the communities from which they flow continue to experience deprivation and environmental degradation due to daily inputs of petroleum hydrocarbon spills and oily wastes discharges [1]. Ibeno is one of the thirty-one (31) LGAs in Akwa Ibom State, Nigeria. It is the location of massive oil deposits, which have been extracted for decades by Mobil Producing Nigeria Unlimited (MPNU), a subsidiary of ExxonMobil Corporation and some marginal oilfield operators like Frontier Oil Ltd and Network Exploration and Production Nigeria Ltd $[2,3]$. Over the years, the rivers, streams, marine and forest which happened to be the major income sources for the majority of the rural dwellers in the region have become highly contaminated due to the O\&G E\&P activities [4].

The presence of petroleum hydrocarbon is considered one of the major factors that influence microbial diversity and succession in polluted water bodies [5]. Diverse groups of microorganisms naturally are capable of hydrocarbon degradation mostly as food due to the ubiquitous distribution of hydrocarbons in the environment from both natural and anthropogenic inputs [6,7]. Numerous genera of bacteria e.g., Staphylococcus, Pseudomonas, Bacillus, Proteus, Micrococcus, Klebsiella, Enterobacter [8]; fungi e.g., Fusarium; [9] and yeasts such as Rhodotorula have been isolated from contaminated aquatic ecosystems and their metabolic activities are strongly considered responsible for the removal of the hydrocarbons from the environment [6].

The gene that encode the small subunit ribosomal RNA is ubiquitous in prokaryotes [10] and serves in the classification of bacteria and archaea owing to its high degree of conservation and its fundamental function in living organisms [11]. It is important to note that several pieces of RNA are important for proper ribosome functions. This RNA is not translated to proteins, the ribosomal RNA is the active component. Thus we refer to the "rRNA gene" or "rDNA" to designate the DNA in the genome that produces the ribosomal RNA. This study was designed to assess the prokaryotic diversity of a remote aviation fuel-contaminated lentic ecosystem after 16 years of aviation fuel pollution alongside a control lentic ecosystem with no history of aviation fuel pollution using $16 \mathrm{~S}$ rRNA gene amplification and sequencing.

\section{Materials and Methods}

\section{Site description and sample collection}

Integrated sampling was carried out at an aviation fuel-polluted lentic ecosystem on longitude $04^{\circ} 32.647^{\prime} \mathrm{N}$, and latitude $007^{\circ} 59.951^{\prime}$ $\mathrm{E}$ and on longitude $04^{\circ} 58.519^{\prime} \mathrm{N}$, and latitude $007^{\circ} 57.908^{\prime} \mathrm{E}$ as the control. Water samples were collected at different points in one-litre pre-washed plastic containers and taken to the laboratory in ice-packed cooler. Samples from individual site were composited and used for the analyses.

\section{Deoxyribonucleic Acid (DNA) extraction, sequencing and bioinformatics analysis}

Community DNA of all the microorganisms was extracted using

*Corresponding author: Ime Udotong, Department of Microbiology, University of Uyo, Uyo, Akwa Ibom State, Nigeria, Tel: +2348146129875; E-mail: ime.udotong@uniuyo.edu.ng

Received July 12, 2017; Accepted July 17, 2017; Published July 22, 2017

Citation: Udotong I, Uko M, Udotong J (2017) Use of 16S rDNA Sequencing to Determine Procaryotic Diversity of a Remote Aviation Fuel-Polluted Lentic Ecosystem in Ibeno, Nigeria. J Environ Anal Toxicol 7: 493. doi: 10.4172/21610525.1000493

Copyright: @ 2017 Udotong I, et al. This is an open-access article distributed under the terms of the Creative Commons Attribution License, which permits unrestricted use, distribution, and reproduction in any medium, provided the original author and source are credited. 
Citation: Udotong I, Uko M, Udotong J (2017) Use of 16S rDNA Sequencing to Determine Procaryotic Diversity of a Remote Aviation Fuel-Polluted Lentic Ecosystem in Ibeno, Nigeria. J Environ Anal Toxicol 7: 493. doi: 10.4172/2161-0525.1000493

Page 2 of 6

the MoBio DNA Extraction Kit. The eluted DNA was centrifuged at room temperature at $10,000 \times \mathrm{g}$ for 30 seconds. The supernatant was discarded leaving the DNA. The DNA was preserved for further analyses at $-20^{\circ}$ to $-80^{\circ} \mathrm{C}$. The concentration of the DNA was examined an ultraviolet absorbance spectrophotometry. DNA amplification involves the duplication of the DNA molecules with each strand serving as template for the duplication. Each strand of the DNA molecule serving as template was amplified by Polymerase Chain Reaction with the aid of $16 \mathrm{~S}$ rRNA primers in a $50 \mu \mathrm{l}$ reaction mixture with the following programme: denaturation at $94^{\circ} \mathrm{C}$ for $3 \mathrm{~min}$, and 30 cycles of $94^{\circ} \mathrm{C}$ for $20 \mathrm{sec}$, annealing at $53^{\circ} \mathrm{C}$ for $30 \mathrm{sec}$, and extension at $68^{\circ} \mathrm{C}$ for $5 \mathrm{~min}$, with a final extension at $68^{\circ} \mathrm{C}$ for $10 \mathrm{~min}$. The PCR products were by agarose gel electrophoresis. PCR products were sequenced using the Miseq Illumina platform. The $16 \mathrm{~S}$ rRNA sequences were analyzed using the Quantitative Insight into Microbial Ecology (QIIME) version 1.8.0 (Figure 1).

\section{Results and Discussion}

Numerous sequences of bacteria and archaea were detected from samples of both water bodies using the $16 \mathrm{~S}$ rDNA sequencing. The method revealed comparable results (Figure 2) indicating a higher bacterial population in the polluted water than that of the control water.
Bacteria showed a high occurrence in the two sites with the percentage composition of $93.83 \%$ in the polluted sample and $58.05 \%$ in the control sample.

Phylum level affiliations of the sequences recovered from the two samples revealed distinct difference in phylum-level community composition. Sequences from 26 and 20 phyla were retrieved form the polluted and control site, respectively. "Other" represents the sum total of all phyla with percentage read of less than one (1). As presented on Table 1, the top / dominant phyla in the bacterial community detected in the polluted water were Unknown, Proteobacteria, Firmicutes, Actinobacteria, Cyanobacteria, and Chloroflexi and represented $37.52 \%, 33.86 \%, 7.31 \%, 6.19 \%, 3.65 \%$ and $2.84 \%$ respectively. The top / dominant phyla in the control water sample were Unknown, Proteobacteria, Firmicutes, and Actinobacteria and represented $21.50 \%$, $39.69 \%, 27.87 \%$ and $2.61 \%$ of all classified sequences from the sample, respectively. Dominant phyla in the archaeal community retrieved for both waters were Euryarchaeota and Crenarchaeota representing $1.33 \%$ and $0.19 \%$ in the polluted sample and $0.24 \%$ and $0.23 \%$ in the control sample.

Sequence affiliated to other phyla like Planctomycetes $(0.11 \%)$, Fibrobacteres $(0.08 \%)$, Deinococcus-thermus $(0.04 \%)$, Fusobacteria

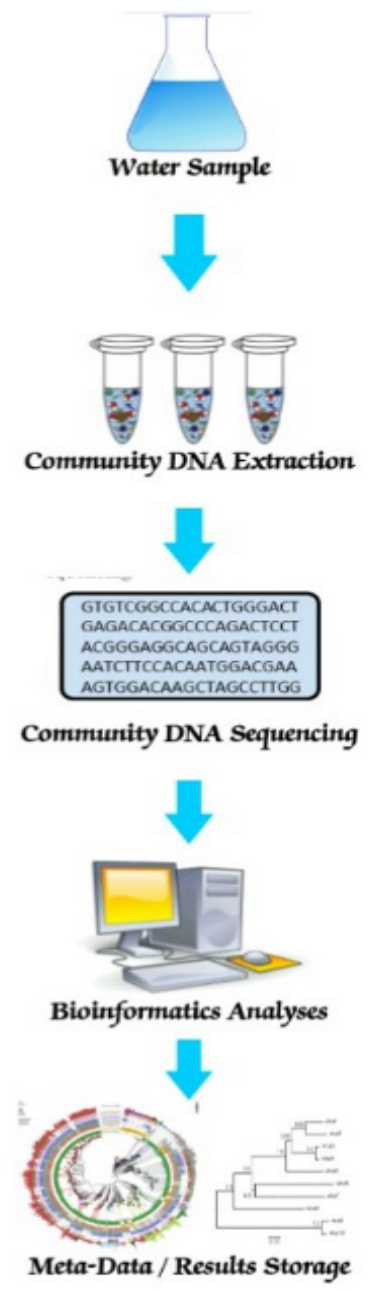

Figure 1: Standard Metagenomics protocol. The dominance of bacteria in the different ecosystems as revealed in this study agrees to our previous findings (Udotong et al.) and is an indication of the water conditions being habitable to the bacterial group. 
Citation: Udotong I, Uko M, Udotong J (2017) Use of 16S rDNA Sequencing to Determine Procaryotic Diversity of a Remote Aviation Fuel-Polluted Lentic Ecosystem in Ibeno, Nigeria. J Environ Anal Toxicol 7: 493. doi: 10.4172/2161-0525.1000493

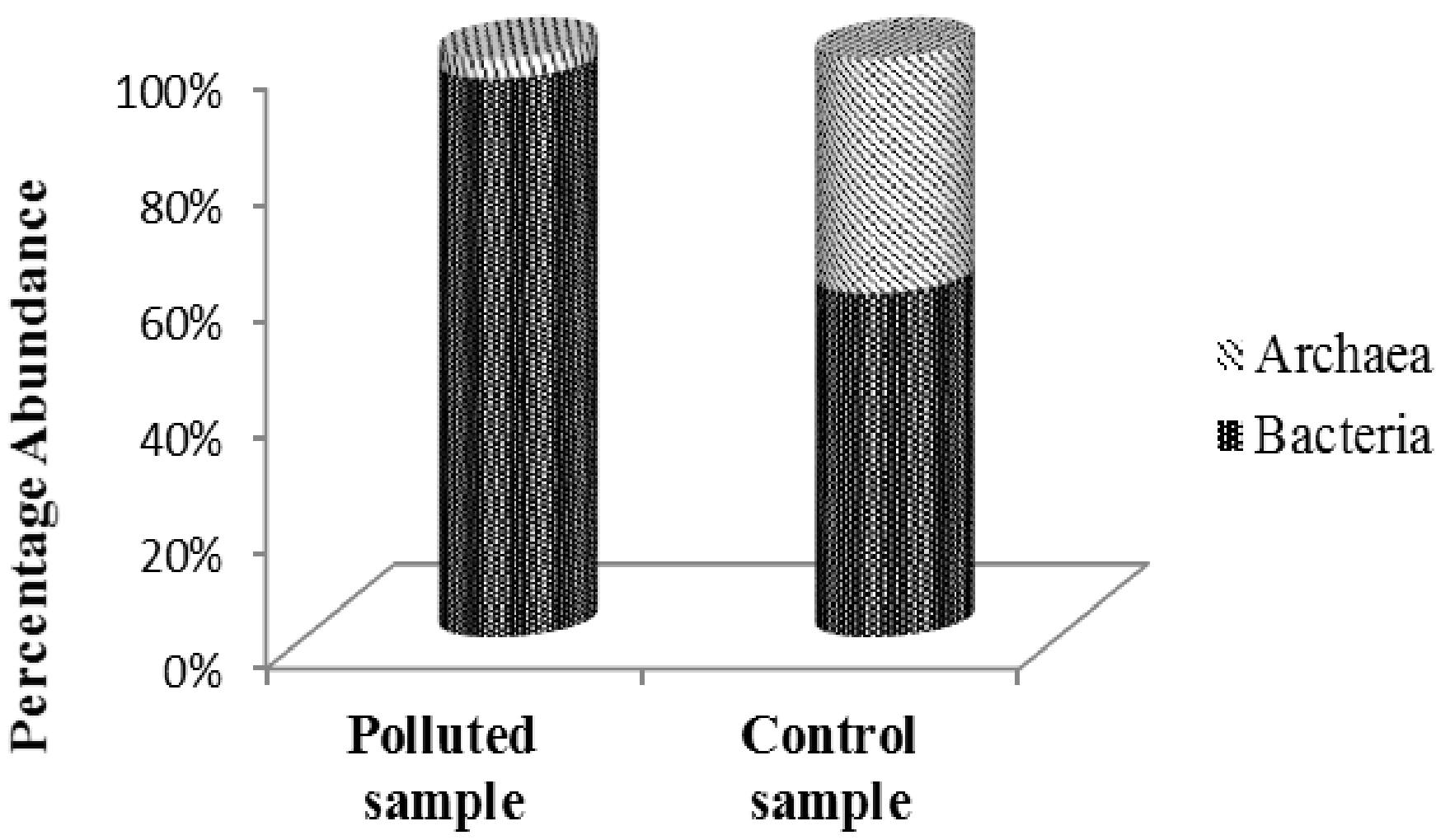

Figure 2: Percentage distribution of short DNA (reads) sequences of bacteria and archaea detected in the aviation fuel-polluted and control water samples.

\begin{tabular}{|c|c|c|c|}
\hline \multirow{2}{*}{ S No } & \multirow{2}{*}{ Phylum } & \multicolumn{2}{|c|}{ Percentage Reads (\%) } \\
\hline 1 & Unknown* & Polluted sample & Control sample \\
\hline 2 & Proteobacteria & 37.52 & 21.50 \\
\hline 3 & Firmicutes & 33.86 & 39.69 \\
\hline 4 & Actinobacteria & 7.31 & 27.87 \\
\hline 5 & Cyanobacteria & 6.19 & 2.61 \\
\hline 6 & Chloroflexi & 3.65 & 0.48 \\
\hline 7 & Bacteroidetes & 2.84 & 0.47 \\
\hline 8 & Ciliophora & 1.88 & 1.37 \\
\hline 9 & Euryarchaeota & 1.82 & 0.57 \\
\hline 10 & Other & 1.33 & 0.24 \\
\hline
\end{tabular}

*Unknown represents all phyla with \% reads of $>1$ but not identified in the database while ** Other is the sum total of all phyla with $\%$ read count of $<1$.

Table 1: Top 8 Phyla and parentage distribution of bacterial and archaeal diversity retrieved from the aviation fuel-polluted and control (unpolluted) water bodies.

$(0.01 \%)$, etc. and Chlorobi $(0.12 \%)$, Spirochaetes $(0.11 \%)$, Aquificae (0.06\%), Gemmatimonadetes (0.05\%), Fibrobacteres (0.03\%), Fusobacteria $(0.02 \%)$ in the contaminated and control samples, respectively, were found in extremely low abundance, as indicated in parentheses.

Sequences belonging to 40 and 34 classes of prokaryotes were retrieved from the polluted and control water samples, respectively. The top 12 Classes are represented on Table 2. Over thirty eight (38.08) percent of sequences retrieved from the polluted water sample and $21.56 \%$ of sequences from the control water sample were affiliated to the class "Unknown". Also, $39.55 \%$ of sequences from the control site had affiliation to the class 'Not assigned' and were the highest in among the classes. While sequences similar to Betaproteobacteria
(20.13\%), Alphaproteobacteria $(8.10 \%)$ and Actinobacteria $(6.17 \%)$ dominated in the contaminated water, Betaproteobacteria $(20.75 \%)$, Gammaproteobacteria (4.29\%) and Actinobacteria (2.57\%) showed highest occurrence in the control sample.

Presented on Table 3 are the sequences retrieved from the polluted water sample that matched those of bacterial and archaeal diversity that belonged to the Order Unknown, Burkholderiales, Actinomycetales, and Rhizobiales while those in the control sample matched the 'Not assigned', Unknown and Burkholderiales, etc.

Table 4 presents the different families of bacteria and archaea identified in the polluted and control water samples. Majority of the detected sequences were affiliated to the family Unknown, with the percentage composition of $44.50 \%$ followed by Alcaligenaceae 
Citation: Udotong I, Uko M, Udotong J (2017) Use of 16S rDNA Sequencing to Determine Procaryotic Diversity of a Remote Aviation Fuel-Polluted Lentic Ecosystem in Ibeno, Nigeria. J Environ Anal Toxicol 7: 493. doi: 10.4172/2161-0525.1000493

Page 4 of 6

\begin{tabular}{|c|c|c|c|}
\hline \multirow{2}{*}{ S No } & \multirow{2}{*}{ Class } & \multicolumn{2}{|c|}{ Percentage Read Count (\%) } \\
\hline & & Polluted sample & Control sample \\
\hline 1 & Not assigned & 0.05 & 39.55 \\
\hline 2 & Unknown* & 38.08 & 21.56 \\
\hline 3 & Betaproteobacteria & 20.13 & 20.75 \\
\hline 4 & Alphaproteobacteria & 8.10 & 1.83 \\
\hline 5 & Actinobacteria & 6.17 & 2.57 \\
\hline 6 & Bacillilaceae & 3.96 & 1.49 \\
\hline 7 & Cyanophyceae & 3.38 & 0.44 \\
\hline 8 & Clostridia & 3.36 & 1.40 \\
\hline 9 & Gammaproteobacteria & 3.07 & 4.29 \\
\hline 10 & Chloroflexi & 2.84 & 0.47 \\
\hline 11 & Deltaproteobacteria & 1.93 & 0.64 \\
\hline 12 & Gymnostomatea & 1.65 & 0.24 \\
\hline 13 & Bacteroidetes & 1.54 & 0.37 \\
\hline 14 & Methanomicrobia & 1.14 & 0.09 \\
\hline 15 & Other** & 4.67 & 6.11 \\
\hline
\end{tabular}

*Unknown are Classes with percentage read count of $>1$ but not identified in the database while ** Other is the sum total of all Classes with percentage read count of $<1$ Table 2: Percentage distribution of top bacterial and arhaeal Classes detected in the aviation fuel-polluted and unpolluted water samples.

\begin{tabular}{|c|c|c|c|}
\hline \multirow{2}{*}{ S No } & \multirow{2}{*}{ Order } & \multicolumn{2}{|c|}{ Percentage Read Count (\%) } \\
\hline & & Polluted sample & Control sample \\
\hline 1 & Not assigned & 0.03 & 39.51 \\
\hline 2 & Unknown* & 42.20 & 25.43 \\
\hline 3 & Burkholderiales & 18.82 & 18.22 \\
\hline 4 & Actinomycetales & 5.39 & 1.93 \\
\hline 5 & Bacillales & 3.78 & 1.40 \\
\hline 6 & Rhizobiales & 4.93 & 0.95 \\
\hline 7 & Chroococcales & 3.38 & 0.44 \\
\hline 8 & Clostridiales & 3.34 & 1.25 \\
\hline 9 & Spathidiida & 1.56 & 0.24 \\
\hline 10 & Bacteroidales & 1.54 & 0.37 \\
\hline 11 & Methanosarcinales & 1.14 & 0.09 \\
\hline 12 & Sphingomonadales & 1.04 & 0.04 \\
\hline 13 & Pseudomonadales & 0.77 & 1.67 \\
\hline 14 & Neisseriales & 0.11 & 1.13 \\
\hline 15 & Other** & 10.05 & 9.32 \\
\hline
\end{tabular}

*Unknown are Orders with percentage read count of $>1$ but not identified in the database while ** Other is the sum total of all Orders with percentage read count of $<1$ Table 3: Representative Order of procaryotes detected in the aviation fuel-polluted and control (unpolluted) water sample.

\begin{tabular}{|c|c|c|c|}
\hline \multirow{2}{*}{ S No } & \multirow{2}{*}{ Family } & \multicolumn{2}{|c|}{ Percentage Read Count (\%) } \\
\hline & & Polluted sample & Control sample \\
\hline 1 & Unknown* & 44.50 & 25.66 \\
\hline 2 & Comamonadaceae & 1.71 & 8.12 \\
\hline 3 & Alcaligenaceae & 16.55 & 0.72 \\
\hline 4 & Bacillaceae & 3.62 & 0.93 \\
\hline 5 & Cyanobacteriaceae & 3.38 & 0.44 \\
\hline 6 & Beijerinckiaceae & 3.06 & - \\
\hline 7 & Streptomycetaceae & 2.78 & 0.77 \\
\hline 8 & Coniocybaceae & 0.03 & 39.51 \\
\hline 9 & Burkholderiaceae & 0.38 & 9.36 \\
\hline 10 & Neisseriaceae & 0.11 & 1.13 \\
\hline 11 & Pseudomonadaceae & 0.36 & 1.11 \\
\hline 12 & Clostridiaceae & 1.33 & 1.04 \\
\hline 13 & Eubacteriaceae & 1.64 & 0.15 \\
\hline 14 & Spathidiidae & 1.56 & 0.24 \\
\hline 15 & Chloroflexaceae & 1.16 & 0.27 \\
\hline 16 & Methanosarcinaceae & 1.14 & 0.04 \\
\hline 17 & Sphingomonadaceae & 1.04 & 0.04 \\
\hline 15 & Other ${ }^{* *}$ & 23.07 & 14.07 \\
\hline
\end{tabular}

*Unknown are Families with percentage read count of $>1$ but not identified in the database while ${ }^{* *}$ Other is the sum total of all Families with percentage read count of $<1$ Table 4: Family classification of prokaryotic sequences detected in the aviation fuel-polluted and unpolluted samples. 
Citation: Udotong I, Uko M, Udotong J (2017) Use of 16S rDNA Sequencing to Determine Procaryotic Diversity of a Remote Aviation Fuel-Polluted Lentic Ecosystem in Ibeno, Nigeria. J Environ Anal Toxicol 7: 493. doi: 10.4172/2161-0525.1000493

Page 5 of 6

\begin{tabular}{|c|c|c|c|c|}
\hline Bacterial and Archaeal Species & Polluted sample & Control sample & $\%$ Identity Match & Accession number \\
\hline Uncultured bacterium & + & - & 93 & KF023595.1 \\
\hline Uncultured bacterium & + & - & 81 & GU632587.1 \\
\hline Mycobacterium sp. & - & + & 95 & LN876401.1 \\
\hline Uncultured bacterium & + & - & 83 & GQ402641.1 \\
\hline Uncultured archaeon & + & - & 96 & KJ645016.1 \\
\hline Acidovorax sp. & - & + & 96 & KR088454.1 \\
\hline Uncultured Streptophyta & - & + & 89 & JQ701246.1 \\
\hline Staphylococcus sp. & - & + & 83 & AJ316320.1 \\
\hline Saprospira sp. & + & + & 98 & AY929064.1 \\
\hline Uncultured Methanosarcina sp. & + & - & 95 & AY454773.1 \\
\hline Achromobacter sp. & + & + & 95 & AM232721.1 \\
\hline Uncultured Gloeothece sp. & + & + & 93 & AY874086.1 \\
\hline Uncultured Verrucomicrobia bacterium & - & + & 73 & AY874030.1 \\
\hline Uncultured Bacteroidetes bacterium & - & + & 95 & AY874003.1 \\
\hline Uncultured Beijerinckia sp. & + & - & 94 & AY806011.1 \\
\hline Streptomyces sp. & + & - & 86 & AB124448.1 \\
\hline Streptomyces sp. & - & + & 91 & AB124529.1 \\
\hline Simkania negevensis & + & + & 98 & SSU68460.2 \\
\hline Pseudomonas aeruginosa & + & + & 81 & AB126582.1 \\
\hline Unidentified bacterium & + & - & 86 & AJ518513.1 \\
\hline Bacillus anthracis & - & + & 83 & AE016879.1 \\
\hline Bacillus sp. & + & - & 85 & AB126768.1 \\
\hline Bacillus sphaericus & + & + & 78 & AY161044.1 \\
\hline Uncultured Chloroflexi bacterium & + & - & 95 & AY921865.1 \\
\hline Acidovorax delafieldii & + & - & 81 & AJ518818.1 \\
\hline Uncultured Chloroflexus sp. & + & + & 95 & AY862018.1 \\
\hline Unidentified eubacterium & + & - & 95 & AJ229218.1 \\
\hline Pseudomonas sp. & - & + & 75 & AJ278108.1 \\
\hline Uncultured Methanosphaera sp. & - & + & 77 & AY454780.1 \\
\hline Uncultured crenarchaeote & - & + & 87 & AY454669.1 \\
\hline Uncultured archaeon & + & - & 96 & DQ146728.1 \\
\hline Spirulina subsalsa & + & + & 95 & AF329394.1 \\
\hline Pyramimonas parkeae & - & + & 98 & AF393608.1 \\
\hline Pseudomonas saccharophila & - & + & 77 & AF396932.1 \\
\hline Bradyrhizobium sp. & - & + & 82 & AF363148.1 \\
\hline Uncultured Methanobacteriaceae & + & - & 91 & AM050403.1 \\
\hline Uncultured candidate division OD1 & + & - & 86 & AY921841.1 \\
\hline Uncultured soil bacterium & + & - & 96 & AY850299.1 \\
\hline Chlorella sorokiniana & - & + & 88 & X65689.1 \\
\hline Leptolyngbya sp. & + & - & 91 & X84809.1 \\
\hline Gemmata obscuriglobus & - & + & 94 & X85248.1 \\
\hline Methylocapsa acidiphila & + & - & 93 & NR_028923.1 \\
\hline
\end{tabular}

Key: +: Detected; -: Not detected

Table 5: Representative diversity of Prokaryotes in Aviation fuel-polluted and unpolluted water samples.

$(16.55 \%)$ in the contaminated water and Coniocybaceae $(39.51 \%)$ and Burkholderiaceae $(9.36 \%)$ in the control water.

This study revealed a higher bacterial diversity in the aviation fuelpolluted water than in the unpolluted water. This may be attributed to presence of petroleum hydrocarbons and their effects on the diversity and population of prokaryotes especially the bacterial group in the freshwater system, an observation earlier reported by Atlas and Bartha [12]. Bacterial and archaeal species with gene sequences affiliated to those present at the two study sites together with their accession numbers are represented on Table 5. Both sites share some species in composition as observed in other taxa and here are indicated with a "+" sign. Majority of the prokaryotic sequences are those of uncultured bacteria as well as uncultured archaea. Some of the species in common include Bacillus sphaericus with accession number AY161044.1, Achromobacter
sp.-AM232721.1, Uncultured Gloeothece sp.-AY874086.1, Pantoea sp.-AJ534866.1, Stigonema ocellatum- AJ544082.1, Pseudomonas aeruginosa-AB126582.1, Simkania negevensis-SSU68460.2, Uncultured Chloroflexus sp.-AY862018.1. Observably, plenty of the species found in the polluted sample are not found in the control sample and vice versa. For example, Methylobacterium sp.-AJ549955.1, Bacillus gibsoniiAB112017.1, Dechloromonas sp.-AY084087.2, Nitrobacter winogradskyi - L11661.1, Methylocapsa acidiphila- NR_028923.1, Methylocystis parvus - AJ458508.1, etc.

\section{Conclusion}

The $16 \mathrm{~S}$ rDNA analysis of the prokaryotic diversity of the remote aviation fuel-polluted and unpolluted lentic ecosystems revealed an enormous composition of bacteria and archaea in both water 
Citation: Udotong I, Uko M, Udotong J (2017) Use of 16S rDNA Sequencing to Determine Procaryotic Diversity of a Remote Aviation Fuel-Polluted Lentic Ecosystem in Ibeno, Nigeria. J Environ Anal Toxicol 7: 493. doi: 10.4172/2161-0525.1000493

Page 6 of 6

bodies. The polluted water had a greater composition of procaryotes. Bacterial community got a higher diversity of the composition in both waters. Archaeal population of the polluted water was remarkably low compared to the high composition observed in the unpolluted and control samples.

According to Ntushelo [13], Approaches to identifying and studying bacterial diversity often relied on the traditional methods of plating bacteria on agar. These approaches are still relevant for culturable bacteria but fall short of detecting fastidious and unculturable bacteria. Molecular-based techniques like targeted sequencing of the 16S rRNA gene from gross DNA samples have facilitated surveys of bacterial diversity. The sequencing and cloning of individual sequences is however tedious and cannot provide a comprehensive survey of a bacterial community. The $16 \mathrm{~S}$ rRNA gene can be amplified from pure bacterial colonies or can be amplified directly from a crude sample. Amplified from a crude sample, the 16S rRNA gene can be massively sequenced using high - throughput sequencing instruments. Direct amplification of the 16S rRNA gene and its massive sequencing has corrected the underrepresentation of bacteria in many bacterial communities. Analysis of bacterial communities is now made easier by the ample data generated from various bacterial communities survey projects, like this hydrocarbon polluted and unpolluted lentic ecosystem $[14,15]$.

\section{References}

1. Udotong IR, Udotong JIR (2007) Environmental Policies and Practices in the oil \& gas industries in Nigeria: Experiences and Lessons learnt so far. A paper presented during the 2nd World Petroleum Council (WPC) / UN Global Compact Forum on "Responsible Business Practices in the Oil \& Gas Sector: Implementing the Global Compact Principles" at Le Meridien Hotel, New Delhi, India on 6-7 December 2007.

2. Udotong IR, Udotong JI, John OU (2015) Delineation of Oil-Polluted Sites in Ibeno LGA, Nigeria, Using Microbiological and Physicochemical Characterization. World Academy of Science, Engineering and Technology. International Journal of Chemical, Molecular, Nuclear, Materials and Metallurgical Engineering 9: 704-708.

3. Udotong IR, Uko MP, Udotong JI (2015) Microbial Diversity of a Remote
Aviation Fuel Contaminated Sediment of a Lentic Ecosystem in Ibeno, Nigeria. Journal of Environmental \& Analytical Toxicology 5: 1.

4. Udotong IR, Udotong JIR (2014) Petroleum Exploration and Production (E\&P) activities and production and management of seafoods: A case study of oil production and fishing activities in Akwa Ibom State, Nigeria. An invited paper presented during the 1st NIFST South-East Chapter Food Summit held at University of Uyo, Uyo, Akwa Ibom State on Thursday, 12-13 June 2014.

5. Kayode-Isola TM, Eniola KI, Olayemi AB, Igunnugbemi OO (2008) Response of resident bacteria of a crude oil-polluted river to diesel oil. American-Eurasian J Agro 1: 6-9.

6. Kumari M, Abraham J (2011) Biodegradation of diesel oil using yeast Rhodosporidium toruloides. Research Journal of Environmental Toxicology 5: 369.

7. Kimes NE, Callaghan AV, Suflita JM, Morris PJ (2014) Microbial transformation of the Deepwater Horizon oil spill-past, present, and future perspectives. Frontiers in Microbiology, p: 5.

8. Chikere CB, Ekwuabu CB (2014) Culture-dependent characterization of hydrocarbon utilizing bacteria in selected crude oil-impacted sites in Bodo, Ogoniland, Nigeria. African Journal of Environmental Science and Technology 8: 401-406.

9. Hidayat A, Tachibana S (2012) Biodegradation of Aliphatic Hydrocarbon in Three Types of Crude Oil by Fusarium sp. F 092 under Stress with Artificial Sea Water. Journal of Environmental Science and Technology 5: 64-73.

10. Olukunle OF, Boboy B (2013) The Molecular Succession of Bacterial Community of Crude Oil Polluted Soil and Water Samples from the Niger Delta, Nigeria. British Journal of Applied Science \& Technology 3: 777.

11. Salman V, Amann R, Shub DA, Schulz-Vogt HN (2012) Multiple self-splicing introns in the 16S rRNA genes of giant sulfur bacteria. Proceedings of the National Academy of Sciences 109: 4203-4208.

12. Atlas RM, Bartha R (1970) Abundance, distribution and oil biodegradation potential of micro-organisms in Raritan Bay. Environmental Pollution 4: 291-300.

13. Ntushelo K (2013) Identifying bacteria and studying bacterial diversity using the $16 \mathrm{~S}$ ribosomal RNA gene-based sequencing techniques: A review. African Journal of Microbiology Research 7: 5533-5540.

14. Kadafa AA (2012) Oil exploration and spillage in the Niger Delta of Nigeria. Civil and Environmental Research 2: 38-51.

15. Obire O, Anyanwu EC (2009) Impact of various concentrations of crude oil on fungal populations of soil. International Journal of Environmental Science \& Technology 6: 211-218. 